\title{
PERAN TEKNOLOGI INFORMASI DALAM SISTEM INFORMASI MANAJEMEN
}

\author{
Robi Pratama Putra \\ Universitas Negeri Padang \\ Padang \\ Indonesia \\ e-mail : Robipratama.rp7@gmail.com
}

\begin{abstract}
Abstrak
Di era globalisasi ini, sangat pesat perkembangan yang terjadi. Baik dalam hal budaya maupun dalam hal IT. Di era serba canggih ini tidak dapat di pastikan apa yang akan terjadi dalam waktu singkat, karna perkembangan sangat pesat pula. Dalam hal ini juga berpengaruh kepada sebuah sistem informasi, dimana sebelumnya informasi bersifat manual dan susah di akses. Namun pada waktu saat ini semua informasi sangat mudah untuk di akses dimanapun kapanpun. Dalam hal ini muncullah sebuah sistem informasi yang disebut Sistem Informasi Manajemen, dimana dengan adanya sistem ini memudahkan semua pihak yang membutuhkan informasi. Dari hal inilah penulis membuat artikel ini untuk mengetahui seperti apakah sistem informasi ini, dan apa kaitannya dengan Teknologi Informasi.
\end{abstract}

Kata Kunci : Teknologi Informasi, Sistem Informasi Manajemen.

\section{Pendahuluan}

Di zaman yang serba canggih dan modern ini sangat banyak perkembangan terjadi. Perkemmbangan yang terjadi bukan hanya pada satu lini saja namun terjadi pada banyak lini. Salah satunya pada Sistem Informasi. Sistem informasi ini merupakan senuah Sistem yang tersusun dengan komplek dan saling berkaitan antar unsur-unsurnya, sehingga terjadi aliran informasi yang sangat komplek dan lengkap.

Sistem Informasi Manajemen (SIM) menurut Windham tahun 1996 (Suryadi, 2016) adalah seperangkat struktur dan prosedur kerja meliputi pengumpulan, pemrosesan, analisis, presentasi dan penggunaan informasi dalam sebuah organisasi. Sedangkan dimensi dari SIM itu sendiri adalah teknologi, konteks manajemen, kerangka kerja konseptual struktur informasi dan bentuk susunan data yang digunakan. Penjelasan lain yang dikembangkan oleh Windham 1996 (Suryadi, 2016), bahwa sebuah SIM akan mencapai keberhasilan bilamana dalam pengoperasionalnya meliputi lima tahap, yakni; identifikasi kebutuhan, pengumpulan data, prosesing dan analisis data, provisi informasi dan utilisasi informasi. 


\section{Pembahasan}

\section{Teknologi Informasi (TI)}

Teknologi informasi merupakan suatu hal yang sangat penting di era 4.0 saat ini. Dimana semua orang berhak untuk akses informasi yang sama setiap waktunya, karna hal ini TI sangat penting dalam zaman modern seperti saat ini. Menurut (Suryadi, 2016) Inti dari komunikasi adalah informasi, sedangkan alat yang digunakan dalam menyampaikan informasi adalah teknologi. Dengan demikian, maka teknologi informasi adalah suatu bentuk penyampaian informasi yang menggunakan kaidah-kaidah bersifat teknologis, baik dengan bantuan alat maupun program dari si pembawa pesan ke yang menjadi objek penerima pesan.

Perkembangan TI ini juga berimbas pada aspek lain seperti pendidikan, sosial, dan budaya sehingga semua aspek tersebut tidak bisa terlepas dari yang namanya Teknologi Informasi. Dengan berkembangnya teknologi infomasi ini memaksa orang-orang agar bisa menggunakan teknologi informasi ini. Sehingga semua orang harus memacu kemampuannya, mengingkatkan kemampuannya, agar tidak tertinggal oleh orang lainnya.

Teknologi informasi ini membawa banyak sekali kebaikan atau manfaat didalam kehidupan sehari-hari. Contoh pertukaran informasi, dengan adanya teknologi informasi orang-orang bisa saling berkomunikasi tampa harus bertatap muka. Selain itu teknologi juga membuat orang-orang jadi mudah dalam hal lainnya seperti : berbelanja, belajar, update berita dan lainnya. Selain membawa kebaikan dan kemudahan, teknologi informasi juga membawa dampak buruk salah satunya informasi hoax yang sangat mudah tersebar dan sangat susah untuk di bendung. Karna itu kita harus berpandai-pandai di dalam menggunakan teknologi informasi ini, agar tidak merugikan kita.

\section{Sistem Informasi Manajemen}

Sistem Informasi Manajemen merupakan sebuah sistem yang banyak digunakan pada saat ini. Penggunaannya bukan hanya di satu bidang akan tetapi pada banyak bidang, seperti bidang pendidikan, bidang ekonomi, bidang bisnis, dan bidang lainnya. Tapi pada artikel ini kita akan membahas sistem informasi manajemen pada bidang pendidikan.

Menurut (Agustiandra, Vindi., \& Sabandi, 2019) Sistem Informasi Manajemen Akademik adalah segala macam hasil interaksi antara elemen di lingkungan akademik untuk menghasilkan informasi yang kemudian dijadikan landasan pengambilan sebuah keputusan, melaksanakan tindakan, baik oleh pelaku proses itu sendiri maupun dari pihak luar sekolah.

Dalam terminologi teknologi informasi, terdapat tiga komponen utama yang melingkupinya, yakni : (1) management information system, atau sistem informasi 
manajemen, (2) hardware (perangkat keras) ,dan (3) faktor manusia. Sistem Informasi Manajemen (SIM) didefinisikan sebagai keterpaduan antara pengguna (user) dan sistem masinal dalam penyediaan informasi untuk mendukung pelaksanaan, manajemen dan fungsi pembuatan keputusan dalam sebuah organisasi.

Sistem Informasi Manajemen (SIM) menurut Windham (1996:308) adalah seperangkat struktur dan prosedur kerja meliputi pengumpulan, pemrosesan, analisis, presentasi dan penggunaan informasi dalam sebuah organisasi. Sedangkan dimensi dari SIM itu sendiri adalah teknologi, konteks manajemen, kerangka kerja konseptual struktur informasi dan bentuk susunan data yang digunakan. Penjelasan lain yang dikembangkan oleh Windham (1996:309), bahwa sebuah SIM akan mencapai keberhasilan bilamana dalam pengoperasionalnya meliputi lima tahap, yakni; identifikasi kebutuhan, pengumpulan data, prosesing dan analisis data, provisi informasi dan utilisasi informasi.

Dari pengertian di atas dapat di tarik kesimpulan bahwa sistem informasi manajemen adalag satu kesatuan unsur-unsur yang saling berkaitan satu sama lain, meliputi kegiatan pengumpulan informasi, penyimpanan informasi, dan pembagian informasi. Dengan kata lain sistem informasi mananjemen merupakan sistem yang digunakan untuk mengelola sebuah informasi agar informasi dapat digunakan sebagaimana mestinya.

\section{Peran Tekonologi Informasi dalam SIM}

Teknologi informasi sangat berguna dalam berbagai aspek, salah satunya dalam sistem informasi manajemen. Dimana dengan adanya Teknologi informasi ini membuat sebuah sistem informasi manajemen ini dapat berjalan dan dioperasikan sebagaimana mestinya seperti saat ini. Jika seandainya tidak ada dukungan dari Teknologi informasi maka SIM tidak akan berjalan. Contohnya : jaringan ada, data ada, akan tetapi teknologi/hardwere untuk menjalan SIM tidak ada, lantas apakah SIM dapat di operasikan? Tentu saja tidak bisa digunakan. Maka dalam hal ini teknologi informasi sangat dibutuhkan dalam menjalankan sebuah sistem informasi manajemen.

Dengan adanya teknologi informasi juga memudahkan pengelolaan sistem informasi manajemen. Karna dalam pelaksanaannya akan lebih mudah diterapkan jika sebuah sistem informasi manajemen didukung dan suport oleh teknologi informasi. Contohnya dalam pengeditan data pada sistem informasi manajemen akan lebih mudah di lakukan apabila menggunakan devaice dari bantuan teknologi informasi seperti komputer, laptop, tab, dan lainnya yang masih berkaitan dengan teknologi pendidikan. Selain dalam pengeditan data teknologi informasi juga memudahkan kita dalam hal pengiriman dan penggunaan data, contohnya : Menggunakan email, Gdrive dan lainnya. 


\section{Kesimpulan}

teknologi informasi adalah suatu bentuk penyampaian informasi yang menggunakan kaidah-kaidah bersifat teknologis, baik dengan bantuan alat maupun program dari si pembawa pesan ke yang menjadi objek penerima pesan. Dengan adanya teknologi informasi semua pekerjaan manusia dapat berjalan lebih mudah. Sistem informasi manajemen adalah satu kesatuan unsur-unsur yang saling berkaitan satu sama lain, meliputi kegiatan pengumpulan informasi, penyimpanan informasi, dan pembagian informasi. Dengan kata lain sistem informasi mananjemen merupakan sistem yang digunakan untuk mengelola sebuah informasi agar informasi dapat digunakan sebagaimana mestinya.

Teknologi informasi sangat berperan dalam pengelolaan sistem informasi manajemen mulai dari entry data, pengelolaan data, dan pengiriman data informasi. Dengan adanya teknologi informasi semua kerja kita dapat berjalan lebih mudah dan lebih cepat. Sehingga pada saat ini tidak susah lagi jika kita ingin mengelolaan sistem informasi manajemen dimanapun dan kapanpun.

\section{Daftar Pustaka}

Agustiandra, Vindi., \& Sabandi, A. (2019). PERSEPSI GURU TERHADAP PENERAPAN SISTEM INFORMASI MANAJEMEN AKADEMIK DI SEKOLAH MENENGAH KEJURUAN (SMK) NEGERI 3 PADANG. 8, 1-8.

Suryadi, D. (2016). Teknologi Informasi Dalam Sistem Informasi Manajemen (SIM)

Pendidikan Menengah Kejuruan. 1-17. 